DOI: $\underline{10.17805 / g g z .2020 .1 .3}$

\title{
Социокультурная субъектность как основа тезаурусной концепции молодежи
}

\author{
А. И. Ковалева
}

Московский гуманитарный университет

Рассмотрены основные позиции тезаурусной конщепџии молодежи. Соииокультурная субъектность осмыслена как соииальный феномен, определяюший активность человеческого фактора в его взаимоотношениях с обществом. Отмечается, что освоение и присвоение сочиокультурной субъектности составляет специфику молодежи.

Ключевые слова: социокультурная субъектность; молодежь; тезаурус; тезаурусный подход; тезаурусная концепџия молодежи; сочиология молодежи; сочиология культуры

\section{Sociocultural Subjectivity as a Foundation of the Thesaurus Conception of Youth}

\author{
V. A. Kovaleva \\ Moscow University for the Humanities
}

The author examines the main points of the thesaurus conception of the youth and thinks over sociocultural subjectivity as a social phenomenon that determines the activity of human factor in its interrelations with society. It is noted that the assimilation and adoption of sociocultural subjectivity is a specific feature of young people.

Keywords: sociocultural subjectivity; youth; thesaurus; thesaurus approach; thesaurus conception of youth; sociology of youth; sociology of culture

\section{ВВЕДЕНИЕ}

Социокультурная субъектность в современной социологии приобретает все большее значение по мере того, как в формирующемся информационном обществе роль «простого человека», которого раньше принято было называть «обывателем» и который был своего рода низшим уровнем воздействия на ход истории в сравнении с «великим человеком»- монархом, миллиардером, выдающимся деятелем искусства и т. д., становится все более ощутимой. В 1980-е гг. было важно различать субъектность и субъективность, поскольку со вторым понятием связывалось представление о личном взгляде на окружающий мир, противопоставленный объективному, научно доказанно- 
му, «правильному» взгляду. Такое различение находим уже в монографии Вал. А. Лукова 1987 г. (Луков, 1987). За прошедшие годы понимание социальной субъектности расширилось, и наиболее удачно оно оказалось применимым к трактовке молодежи в аспекте тезаурусного подхода к ней.

По словам Вал. А. Лукова, «социокультурная субъектность молодежи является основным приобретаемым ею социальным и культурным свойством, преодоление неполноты которого составляет суть ее самореализации в обществе и отношения других возрастных групп к ней» (Луков, 2019а: 12-13). Это позиция составляет основу выдвинутой им тезаурусной концепции молодежи. В декабре 2019 г. эта концепция была представлена научному сообществу в форме докторской диссертации по социологическим наукам (22.00.06 - социология культуры).

Диссертационный совет, обсуждавший диссертацию (Луков, 2019b), отметил, что тезаурусная концепция молодежи реализует методологический тезаурусный подход и обеспечивает последовательную связь «положений концепции с трехчастной трактовкой молодежи (социальная общность; ее тезаурусы; ее вещный и символический мир)» (там же: 364). В центр трактовки молодежи поставлено освоение ею социокультурной субъектности, что подтверждено данными и фактами проведенных при руководстве и участии Вал. А. Лукова эмпирическими исследованиями, а также анализом практики государственной молодежной политики с конца 1980-х гг. до настоящего времени. При этом им доказано, что два компонента - воспитание и молодежная политика - играют основную роль в раскрытии, обосновании, а затем внедрении в жизнь различных мер по формированию у молодежи основ культурного восприятия и освоения действительности.

\section{ТЕЗАУРУСНАЯ КОНЦЕПЦИЯ МОЛОДЕЖИ: \\ ОЦЕНКИ И ПЕРСПЕКТИВЫ РАЗВИТИЯ}

Тезаурусная концепция молодежи сложилась в рамках научной школы молодежных исследований МосГУ (Ковалева и др., 2018ab). Эта концепция также имеет своим источником многочисленные теории молодежи, выдвинутые в XX и в XXI столетиях в России, СССР, США, Германии, Болгарии, Польше, Австрии, Франции, Румынии, Великобритании и других странах. Они существенно отличаются своей направленностью, назначением, формой представления, почему их анализ велся и в отечественной, и зарубежной гуманитаристике нередко фрагментарно.

В период формирования тезаурусной концепции молодежи Вал. А. Луков структурировал этапы становления и развития теорий молодежи с периода их зарождения, провел их классификацию и выявил социологические черты этих теорий там, где они произошли от других систем научного знания 
(биология, психология, антропология и др.), в том числе с привлечением новых источников. Наиболее значительной в этом плане стала его монография «Теории молодежи» (Луков, 2012), получившая признание в научном сообществе (Кузнецова, 2014; Ковалева, Левичева, 2014), хотя и раньше его работы опирались на теоретические труды в области молодежных исследований, особенно в книге «Социология молодежи: теоретические проблемы» (Ковалева, Луков, 1999). В итоге классификация теорий молодежи, сформированная Вал. А. Луковым, включила:

«а) биологически и психологически ориентированные теории молодежи, в которых молодежь представлена как носитель психофизических свойств молодости (Г. С. Холл, Ш. Бюлер, В. Штерн, Э. Эриксон и др.);

б) культурологически и антропологически ориентированные теории молодежи, в которых молодежь характеризуется как феномен культуры (Э. Шпрангер, Ш. Эйзенштадт, М. Карват, В. Миляновский, М. Мид и др.);

в) социологически ориентированные теории молодежи, где она рассматривается в контекстах социальной структуры, социальных институтов и процессов (Т. Парсонс, И. С. Кон, П.-Э. Митев, В. Фридрих, И. М. Ильинский, М. К. Горшков, Л. Розенмайр, Ф. Малер, Л. Махачек и др.). В числе теорий молодежи всех трех групп имеются теории, которые основываются на ее социокультурной субъектности. Из них наиболее последовательны гуманистическая концепция молодежи И. М. Ильинского, концепция культурной нормализации молодежи Е. Л. Омельченко, рискологическая концепция молодежи Ю. А. Зубок. Разные трактовки молодежи в этих теориях представляют по принципу дополнительности ее социокультурную субъектность» (Луков, 2019а: 13).

На этом фоне видна и теоретическая значимость исследования социокультурной субъектности молодежи, которая сформирована в Институте фундаментальных и прикладных исследований МосГУ. Она состоит, во-первых, в том, что в опоре на тезаурусный подход доказано: освоение социокультурной субъектности является основным приобретаемым свойством молодежи, «преодоление неполноты которого составляет суть ее самореализации в обществе...» (Луков, 2019b: 19); этот вывод придает новый ракурс в формировании обобщающих теорий молодежи и противостоит утвердившимся на Западе концепциям «конфликта поколений», ведущей роли молодежи в утверждении принципиально нового общества и др. Во-вторых, ее значимость подтверждается тем, что применительно к проблематике проведенных в ИФПИ исследований молодежи результативно использованы зарубежные и отечественные теории молодежи, данные эмпирических исследований относительно молодежных организаций, субкультур и солидарностей. В-третьих, изложена оригинальная трактовка тезаурусного подхода, включая 
выделение сути тезаурусов «как ориентационных и сверхориентационных ментальных комплексов социального субъекта», факторов конструирования тезаурусов, их элементов, структуры, свойств, области применения в социологических науках (там же: 16). Эта работа проведена первоначально в рамках тезаурусного анализа мировой культуры (Луков В., Луков Вл., 2008, 2013), была поддержана научным сообществом (Гуревич, 2008; Костина, 2008; Болотин, 2009; Ищенко, 2009; Выборнова, 2013); затем - расширена, перенесена во многие отрасти гуманитарного знания, и тезаурусный подход успешно стал применяться во многих работах сотрудников ИФПИ и других научных организаций (Захаров, 2008; Гайдин, 2011; Ламажаа, 2012; Тезаурусы мировой культуры и литературы, 2015; Завьялова, 2018; Канарш, 2020; Кузнецова, 2020). Применение тезаурусного подхода в его расширенном виде позволило, в частности, раскрыть существенные проявления теории молодежи, связанные с выдвижением теоретической идеи биосоциологии молодежи (Луков, 2013, 2018) в аспекте ее социокультурной субъектности. И главное - применить тезаурусный подход в ряду субъектно-ориентированных социологических теорий для трактовки социокультурной субъектности как «активной и автономной от других социальных и культурных факторов роли социального субъекта в сохранении и преобразовании общества в его конкретно-исторической форме» (Луков, 2019b: 16), а также ее освоения молодежью. А это значит, что освоение молодежью социальной субъектности не может быть выявлено и интерпретировано «вне ее объективных оснований - социально-экономических, культурных, политических условий, образе и стиле жизни, ценностно-нормативной системы и др.» (там же: 19). Это «рамка достижимого уровня субъектности, в том числе и применительно к молодежи» (там же).

Такая трактовка молодежи и ее свойств не была обязательным требованием к работам по молодежной проблематике, представлявшим МосГУ. Надо отметить, что в декабре 1991 г. в Институте молодежи (ныне - МосГУ) проходили первые защиты диссертаций на соискание ученой степени по социологическим специальностям, а за годы функционирования диссертационного совета в нем защищено 145 кандидатских и 19 докторских диссертаций. При этом многие исследования были проведены по молодежной проблематике, и именно это было важно для развития научной школы молодежных исследований. Посредством анализа «ценностных ориентаций, идентичностей и инновационной активности молодежи, включая прежде всего коллективные формы молодежного движения» (там же), конструирование государственной молодежной политики в конечном счете пролегал путь к утверждению, что «свое - чужое - чуждое» как первоэлементы тезауруса в молодежной среде отличаются. 
Показательна высокая оценка тезаурусной концепции молодежи ведущими социологами — исследователями молодежных проблем.

Среди них видный российский исследователь молодежи и молодежной политики Людмила Арнольдовна Гегель. Ее основная тема - выявление ключевых проблем развития молодежной политики в Российской Федерации (Гегель, Казакова, 2015ab, 2018; Гегель, Казакова, Косых, 2016). Положительная оценка вытекающей из тезаурусной концепции молодежи системы практических рекомендаций, применимых при формировании государственной молодежной политики, частью отражает то, что Вал. А. Луков - один из главных разработчиков законопроекта «Об общих началах государственной молодежной политики в СССР», готовившегося в Научно-исследовательском центре ВКШ и принятого в 1991 г. на основе этого законопроекта в качестве Закона СССР. Потом ученый возглавлял законотворческие группы Государственной думы РФ, группы по подготовке ряда региональных законопроектов по вопросам молодежи и детей, государственной молодежной политики. Но особо здесь важно то, что конструирование и корректировка молодежной политики оказались связанными с теоретической идеей, непосредственно не вытекающей из задач управления процессами и людьми.

Подобным образом важна и положительная оценка концепции, данная видным представителем иной позиции в социологии молодежи, какая получила большой резонанс в современном научном сообществе. Речь идет об одной из наиболее творческих и бескомпромиссных исследовательниц молодежи, признанной не только в России, но и за рубежом Елене Леонидовне Омельченко (Омельченко, 2019; Омельченко, Поляков, 2017). Она предложила и в непростых условиях защитила оригинальную теорию молодежи, через свои исследования и исследования своих соратников и учеников показала продуктивность выдвинутых концептуальных идей, ставших теоретической базой Центра молодежных исследований в Санкт-Петербургском филиале Высшей школы экономики (директором этого Центра она является). Теория Омельченко нашла отражение в тезаурусной концепции молодежи. Мы помним, что Омельченко одна из первых в стране поддержала принадлежащую Лукову трактовку молодежи через субъектность (Омельченко, 2004).

Особо важна поддержка тезаурусной концепции молодежи Центром социологии молодежи ИСПИ РАН - единственным академическим подразделением, имеющим молодежь основным предметом изучения. Руководимый Юлией Альбертовной Зубок Центр сосредоточил в себе и новые направления в теории, и обширные эмпирические исследования по молодежной проблематике. В Центре работает ведущий российский социолог Владимир Ильич Чупров, который входил в первую группу социологов ЦК ВЛКСМ, и успех этой группы определил возрождение социологии в период хрущевской оттепели 
- не только в применении к молодежи, но и в целом социологии как науки. Знаменательно, что тезаурусная концепция молодежи опирается, среди других, и на теорию социального развития молодежи В. И. Чупрова (Чупров, 1994), многие годы возглавлявшего молодежное направление в академической науке, и на рискологическую теорию молодежи Ю. А. Зубок (Зубок, 2003, 2007) - теорию, возникшую в этом институте. Наконец, очень важно, что ИСПИ РАН активно развивает концепции Чупрова и Зубок в своих новейших исследованиях: только в 2018-2019 гг. вышли по крайней мере 10 объемных книг Института, где обстоятельно представлена молодежная тематика, включая и работы Центра, и другие книги, в частности Татьяны Керимовны Ростовской, заместителя директора ИСПИ РАН (Молодежная политика ... , 2018). Таким образом, основные положения концепции поддержаны не только одним из институтов РАН, не только крупным социологическим учреждением, но и активными участниками масштабных молодежных исследований.

Концепция Вал. А. Лукова посвящена важной социальной проблеме, обозначенной в заявленной теме тремя социальными феноменами (молодежь, субъектность и социокультурные основания). Это междисциплинарная проблема, изучаемая наряду с социологией психологией, философией, антропологией, культурологией и другими науками. Предпринятый в данной концепции социологический срез проблемы обозначен как социокультурные основания субъектности молодежи. В центре внимания автора здесь - молодежное движение, молодежные субкультуры, молодежные «солидарности». Такой ракурс в отношении исследований молодежи рассматривается впервые.

Значительное количество исследовательских работ по различным аспектам субъектности (активность молодежи в тех или иных видах деятельности, ее субкультуры, самоидентификация молодежи и т. д.) пока не получало обобщения в виде теоретической концепции, проясняющей, что же такое субъектность и что в ее изучении представлено в проблемном поле социологии, какие процедуры квантификации возможны для количественного измерения качественных признаков субъектности. Конечно, этот социальный феномен, представляющий собой способность субъекта вести самостоятельную и ответственную жизнь, формируя и при необходимости изменяя себя, только в определенном смысле становится предметом социологического исследования. Способности изучают психологи. Но внешняя, деятельностная сторона проявлений субъектности индивида изучается и социологами (как, впрочем, и других субъектов, но здесь нас интересует именно социокультурная субъектность личности). Для дальнейшего изучения социальной субъектности молодежи представляются актуальными исследования особенностей это- 
го феномена у представителей разных социальных слоев, ценностных ориентаций, идентичностей и инновационной активности молодежи, различных форм молодежного движения, а также прояснения специфики социальной субъектности в виртуализированном обществе, гендерных особенностей субъектности, специфики субъектности старших подростков и т. д.

В начале 90-х годов XX в. известный отечественный социолог В. А. Ядов писал, что Россия переживает становление новой социальной субъектности (Ядов, 1994). В «новой» субъектности он, видимо, видел такую, которая образуется у индивидов в новое время и отличит Россию от советского общества. По Ядову, главным качеством советского общества была бессубъектность индивида, т. е. роль «винтика» в государственном организме для самоопределяющегося индивида. Но возможно предположить, что социальная субъектность индивида складывается в любом обществе и зависит как от характера социальности общества, так и от личностных особенностей индивида. Бессубъектного общества не бывает.

Общество обуславливает типическое в личностях, задавая отработанные и оправдавшие себя в жизнедеятельности людей социокультурные символы и образцы, а также социокультурные рамки субъектности индивидов. Оно заинтересовано в высокой степени конформизма индивидов и их социальной идентичности, что важно для самовоспроизводства общества и обеспечения высокого уровня его саморегуляции. Степень активности субъекта зависит от социокультурных условий и его личностных особенностей.

Современное российское общество как общество социального неравенства, неустойчивости, неопределенности, отсутствия идеологии и какоголибо вектора общественного развития обладает как благоприятными условиями, так и многими ограничениями в освоении и присвоении социальной субъектности индивидами, в особенности молодежного возраста. В этом аспекте в тезаурусной концепции раскрыты основные черты социализации, которая в ее свете предстает именно как социологическая теория (Луков, 2002, 2020). В частности, трактовка вторичной социализации молодежи обогащает представления об освоении молодежью социокультурной субъектности в соответствии с тезаурусами профессиональных сообществ.

В итоге концепцию важно понять не просто как еще одну работу по социологии молодежи, а как работу, вводящую новую методологию. Здесь новизна в том, что тезаурусная концепция введена в качестве методологии в социологию молодежи, но за ней стоит научная школа, которая относится не только к социологии, но и к философии и культурологии. Определяя тезаурус как субъектную организацию знания, концепция исходит из того, что субъектная организация знания - понятие, очень близкое к понятию картины мира, более того, картина мира и представлена как ядро тезауруса. Подчерк- 
нем, что картина мира - это тоже наше знание о мире, но оно носит скорее не рациональный, а эмоциональный характер. И тезаурус, следовательно, не только совокупность рационального знания.

В таком подходе есть аналогия с символической вселенной представителя Марбургской школы неокантианства Э. Кассирера. Методология неокантианства в концепции Вал. А. Лукова представлена через работы Баденской школы, но было бы уместно увидеть в тезаурусном подходе и связь с культурологическими идеями Кассирера, особое внимание уделявшего таким сумевшим выжить в сложной многовековой борьбе идей формам символического освоения человеком мира, как миф и ритуал. Развитие тезаурусной идеи в духе того, что уже сделано применительно к молодежи, наполнилось бы через философию символических форм важным новым смыслом. Соединение позиций по видимости разнородной классики - здесь и М. Вербер, который говорит о ценностях, и П. Сорокин с идеями социокультурной динамики, и социальная экология Чикагской социологической школы, и отечественная школа ценностного содержания морали О. Г. Дробницкого - не создало эклектику. Очень важно, что данная концепция, обладая несомненной новизной, стоит на прочном методологическом фундаменте. Это свидетельствует о доказательности, о том, что выдвинутая концепция имеет полное право на существование.

Имеет значение и то, что многочисленные публикации Вал. А. Лукова освещают выдвинутую концепцию в разных аспектах. Из 630 опубликованных им работ 73 монографии и статьи общим объемом 380,0 п. л. посвящены применению тезаурусного подхода в сфере молодежных исследований. В этом числе есть работы, в которых раскрываются сущность тезаурусов и тезаурусного подхода, его методология, его применимость в социологии культуры, к различным аспектам биосоциологии молодежи, проблемам понимания и воспитания в связи с социализацией молодежи, анализу теорий молодежи, их свойствам, итогам социологических исследований о различных категориях российской молодежи, ее ценностным ориентациям, ее исторической памяти, отношению молодежи к проектам «улучшения» человека, выдвигаемым трансгуманизмом, перспективам развития организованного молодежного движения в России, особенностям молодежных субкультур, российской и мировой практике реализации в обществе государственной молодежной политики и др.

Тезаурусная концепция молодежи построена на синтезе подходов, применяемых в субъектно-ориентированных теориях социологии, авторских разработок общеметодологического тезаурусного подхода, примененного к молодежной проблематике в аспекте социологии культуры, на выводах из обширного материала эмпирических исследований, проведенных в различ- 
ных регионах России и охватывающих длительный срок развития социальных и культурных процессов в молодежной среде, в различных возрастных, профессиональных, гендерных и т. д. группах молодежи (1990-2010-е гг.). Идея, положенная в основу концепции, базируется на анализе теоретических построений зарубежных и отечественных специалистов в сфере социологии культуры и социологии молодежи, обобщении полученных ими выводов, что позволило Вал. А. Лукову и его коллегам по ИФПИ и кафедре социологии МосГУ в ходе многолетних изысканий в области изучения проблематики молодежи, молодежного движения, молодежной политики получить достоверные и научно-обоснованные выводы и результаты исследования.

Значение полученных в ходе этой работы выводов для практики подтверждается тем, что:

- разработана и внедрена концепция государственной молодежной политики (принятие соответствующих федеральных и региональных законов, других нормативных правовых актов РФ и ряда регионов, государственные доклады о положении российской молодежи и др.), учитывающая фактор социокультурной субъектности молодежи, а также показано, что тезаурусная концепция молодежи может применяться как основа концептуализации в последующих документах государственной молодежной политики;

- создана система практических рекомендаций, применимых при формировании государственной молодежной политики на федеральном, региональном и местном уровнях — на основе авторской теоретической конструкции относительно освоения молодежью социокультурной субъектности;

- представлены признаки изменений в идентификации молодежи и на этой основе задачи воспитания, а также проектирования государственной молодежной политики поставлены в связь с ожидаемой социокультурной субъектностью молодежи.

\section{ЗАКЛЮЧЕНИЕ}

В постановке и решении научной и практически значимой проблемы, имеющей важное культурное значение и составившей основу выдвигаемой авторской тезаурусной концепции молодежи значителен и личный вклад Вал. А. Лукова. Им показано, что «социокультурные основания субъектности российской молодежи проявляются в единстве общественных и культурных условий, определяющих социализацию и повседневность молодежи, освоение ею социализационных норм, что... ведет к формированию идентичности со своим народом и с Россией в целом» (Луков, 2019b: 364). Важной составляющей этих оснований является наличие форм молодежного движения (организации, субкультуры, солидарности), позволяющих в коллективных формах осваивать социокультурную субъектность. По результатам эмпирических 
исследований, проведенных под руководством и при участии Вал. А. Лукова в разных регионах РФ, «показано, что социокультурная субъектность имеет на практике разную степень освоенности и неоднозначность проявлений в молодежной среде, что влияет на направленность и динамику социокультурных изменений в России» (там же: 366). Все это подтверждает верность предложенной им гипотезы и подчеркивает «актуальность тезаурусной концепции молодежи, построенной на положении о ведущем свойстве молодежи, состоящем в освоении и присвоении ею социокультурной субъектности», т. е. способности принимать решения и совершать действия, «опираясь на сформировавшиеся под воздействием бесчисленных и разнонаправленных социализационных влияний, устоявшихся в определенных кругах представлений о прошлом, настоящем и будущем, на культурные картины мира» (там же).

\section{СПИСОК ЛИТЕРАТУРЫ}

Болотин, И. С. (2009) Тезаурусы как инструмент преподавателя [Рец. на кн.: Луков В. А., Луков Вл. А. Тезаурусы: субъектная организация гуманитарного знания. М. : Изд-во Нац. ин-та бизнеса, 2008. 784 с.] // Высшее образование в России. № 5. С. 169-172.

Выборнова, В. В. (2013) О новых подходах к тезаурусным исследованиям молодежных проблем [Электронный ресурс] // Информационный гуманитарный портал «Знание. Понимание. Умение». № 1 (январь - февраль). URL: http://zpu-journal.ru/e-zpu/2013/1/Vybornova_Thesaurus-Investigations [apхивировано в WaybackMachine] (дата обращения: 19.01.2020).

Гайдин, Б. Н. (2011) Вечные образы как константы культуры: тезаурусный анализ «гамлетовского вопроса» : монография. Saarbrücken : Lambert Academic Publishing. 212 c.

Гегель, Л. А., Казакова, Е. О. (2015а) Молодежная политика в России: тенденции и перспективы // Alma mater (Вестник высшей школы). №6. С. 110-113.

Гегель, Л. А., Казакова, Е. О. (2015b) Ключевые проблемы развития молодежной политики в Российской Федерации // Социально-гуманитарные знания. № 3. С. 161-174.

Гегель, Л. А., Казакова, Е. О. (2018) Специалист по работе с молодежью: проблемы подготовки и востребованности // Высшее образование в России. Т. 27. № 2. С. 88-94.

Гегель, Л. А., Казакова, Е. О., Косых, О. И. (2016) Государственная молодежная политика: российский и зарубежный опыт преодоления экстремизма // Alma mater (Вестник высшей школы). № 5. С. 59-64. DOI: 10.20339/AM. $\underline{05-16.059}$ 
Гуревич, П. С. (2008) [Рец. на кн.: Луков В. А., Луков Вл. А. Тезаурусы: субъектная организация гуманитарного знания. М., 2008. 784 с.] // Эдип. № 3 (6). С. 165-166.

Завьялова, Н. А. (2018) Культурно-коммуникативные формулы как отражение цивилизационных картин мира : автореф. дис. ... д-ра культурологии. М. 40 с.

Захаров, Н. В. (2008) Шекспиризм русской классической литературы: тезаурусный анализ : монография / отв. ред. Вл. А. Луков. М. : Изд-во Моск. гуманит. ун-та. 320 с.

Зубок, Ю. А. (2003) Проблемы риска в социологии молодежи. М. : Моск. гуманит.-социальн. академия. 268 с.

Зубок, Ю. А. (2007) Феномен риска в социологии: опыт исследования молодежи. М. : Мысль. 288 с.

Ищенко, Ю. А. (2009) Размышления над книгой [Луков В. А., Луков Вл. А. Тезаурусы: субъектная организация гуманитарного знания. М. : Изд-во Нац. ин-та бизнеса, 2008. 784 с.] // Знание. Понимание. Умение. № 3. С. 262268.

Канарш, Г. Ю. (2020) Справедливость, демократия, капитализм: пути модернизации России в XXI веке / Ин-т философии РАН. М. : Ленанд. 304 с.

Ковалева, А. И. (2018а) Социология молодежи: научная школа Московского гуманитарного университета : в 2 ч. / А. И. Ковалева, В. А. Луков, В. А. Гневашева, С. В. Луков. М. : Изд-во Моск. гуманит. ун-та. Ч. 2. 508 с.

Ковалева, А. И. (2018b) Учебно-воспитательный процесс в оценках студентов (мониторинг в Московском гуманитарном университете: этап 2018 г.) / А. И. Ковалева, В. А. Луков, В. А. Гневашева, С. В. Луков [Электронный pecypc] // Горизонты гуманитарного знания. № 3. С. 21-45. URL: http://journals.mosgu.ru/ggz/article/view/796 (дата обращения: 19.01.2020). DOI: 10.178 05/ggz.2018.3.2

Ковалева, А. И., Левичева, В. Ф. (2014) [Рец. на кн.:] Луков Вал. А. Теории молодежи: междисциплинарный анализ. М. : Изд-во «Канон+», 2012 // Социологические исследования. № 4 (360). С. 153-155.

Ковалева, А. И., Луков, В. А. (1999) Социология молодежи: теоретические вопросы. М. : Социум. $351 \mathrm{c}$.

Костина, А. В. (2008) Тезаурусный подход как новая парадигма гуманитарного знания // Обсерватория культуры. № 5. С. 102-109.

Кузнецова, Т. Ф. (2014) О концептуализации молодежи. Вал. А. Луков. Теории молодежи: междисциплинарный анализ. М. : «Канон+» РООИ «Реабилитация», 2012. 528 с. // Философские науки. № 12. С. 134-137. 
Кузнецова, Т. Ф. (2020) Цифровое общество, цифровая культура и гуманитаризация высшего образования: тезаурусный подход : науч. монография. М. : Изд-во Моск. гуманит. ун-та. 192 с.

Ламажаа, Ч. К. (2012) Тезаурусный подход для тувиноведения // Знание. Понимание. Умение. № 2. С. 38-45.

Луков, В. А. (1987) Молодежное движение в социалистическом обществе: вопросы теории и практики. М. : Молодая гвардия. 222 с.

Луков, В. А. (2002) Тезаурусная концепция социализации // Дискурс: социологическая студия. Вып. 2: Социальная структура, социальные институты и процессы / под общ. ред. В. А. Лукова. М. : Социум. 239 с. С. 8-19.

Луков, В. А. (2012) Теории молодежи: междисциплинарный анализ. М. : «Канон+» РООИ «Реабилитация». 528 с.

Луков, В. А. (2013) Биосоциология молодежи: теоретикометодологические основания : науч. монография. М. : Изд-во Моск. гуманит. ун-та. 430 с. Режим доступа: http://mosgu.ru/nauchnaya/publications/2013/monographs/Lukov Biosociology-of-Youth.pdf [архивировано в WaybackMachine] (дата обращения: 19.01.2020).

Луков, В. А. (2018) Российская молодежь о биотехнологических проектах «улучшения» человека // Социологические исследования. № 4 (408). С. 73-81. DOI: $\underline{10.7868 / S 0132162518040086}$

Луков, В. А. (2019а) Социокультурные основания субъектности российской молодежи (тезаурусная концепция молодежи) : автореф. дис. ... д-ра социол. наук. М. 42 с.

Луков, В. А. (2019b) Социокультурные основания субъектности российской молодежи (тезаурусная концепция молодежи) : дис. ... д-ра социол. наук. М. 438 с. Режим доступа: https://mosgu.ru/aspirantura/dissovet/razmesenie _disser/july-2019/Диссертация\%20Вал.А.\%20Лукова.pdf [архивировано в WaybackMachine] (дата обращения: 19.01.2020).

Луков, В. А. (2020) Социализация молодежи как системообразующее понятие науки об обществе: тезаурусный подход // Ученый совет. № 4 (184). C. 16-25.

Луков, В. А., Луков, Вл. А. (2008) Тезаурусы: субъектная организация гуманитарного знания. М. : Изд-во Нац. ин-та бизнеса. 784 с.

Луков, В. А., Луков, Вл. А. (2013) Тезаурусы II: тезаурусный подход к пониманию человека и его мира. М. : Изд-во Нац. ин-та бизнеса. 640 с.

Молодежная политика в системе формирования гражданской идентичности современной молодежи (2018) : кол. монография / под ред. А. В. Бугаева, Т. К. Ростовской. М. : Изд-во Рос. гос. соц. ун-та. 198 с.

Омельченко, Е. Л. (2004) Молодежь: открытый вопрос. Ульяновск : Симбирская книга. $181 \mathrm{c.}$ 
Омельченко, Е. Л. (2019) Уникален ли российский случай трансформации молодежных культурных практик? // Мониторинг общественного мнения: экономические и социальные перемены. № 1 (149). С. 3-27. DOI: 10. 14515/monitoring.2019.1.01

Омельченко, Е. Л., Поляков, С. И. (2017) Концепт культурной сцены как теоретическая перспектива и инструмент анализа городских молодежных сообществ // Социологическое обозрение. Т. 16. № 2. С. 111-132. DOI: 10.17 323/1728-192Х-2017-2-111-132

Тезаурусы мировой культуры и литературы (2015) : мат. Всерос. заочн. науч.-практич. конференции с междунар. участием (19-20 марта 2015 г.) / под ред. Н. Е. Ерофеевой. Орск : Изд-во Орск. гуманит.-технол. ин-та (филиала) ОГУ. 133 с.

Чупров, В. И. (1994) Теоретические и прикладные проблемы социального развития молодежи : автореф. дис. ... д-ра социол. наук. М. 59 с.

Ядов, В. А. (1994) Социальная идентификация в кризисном обществе // Социологический журнал. № 1. С. 35-52.

Дата поступления: 20.02.2020 2.

\section{REFERENCES}

Bolotin, I. S. (2009) Tezaurusy kak instrument prepodavatelia [Rets. na kn.: Lukov V. A., Lukov Vl. A. Tezaurusy: sub"ektnaia organizatsiia gumanitarnogo znaniia. M. : Izd-vo Nats. in-ta biznesa, 2008. 784 s.] [Thesaurus as a lecturer's tool [A review on: Lukov, V. A. and Lukov, Vl. A. Thesauri: The subjective organization of humanities knowledge. Moscow : The National Institute of Business Publ., 2008. 784 p.]]. Vysshee obrazovanie v Rossii, no. 5, pp. 169-172. (In Russ.).

Vybornova, V. V. (2013) O novykh podkhodakh k tezaurusnym issledovaniiam molodezhnykh problem [On the new approaches to thesaurus investigations into youth's problems]. Informatsionnyi gumanitarnyi portal "Znanie. Ponimanie. Umenie”, no. 1 (January — February). [online] Available at: http://zpu-journal.ru/ e-zpu/2013/1/Vybornova_Thesaurus-Investigations/ [archived in WaybackMachine] (accessed 19.01.2020). (In Russ.).

Gaydin, B. N. (2011) Vechnye obrazy kak konstanty kul'tury: tezaurusnyi analiz «gamletovskogo voprosa» [Eternal images as constants of culture: A thesaurus analysis of the "Hamlet's question"] : A monograph. Saarbrücken : Lambert Academic Publishing. 212 p. (In Russ.).

Gegel, L. A. and Kazakova, E. O. (2015a) Molodezhnaia politika v Rossii: tendentsii i perspektivy [Youth policy in Russia: Tendencies and prospects]. Alma mater (Vestnik vysshei shkoly), no. 6, pp. 110-113. (In Russ.). 
Gegel, L. A. and Kazakova, E. O. (2015b) Kliuchevye problemy razvitiia molodezhnoi politiki v Rossiiskoi Federatsii [Key problems of development of youth policy in the Russian Federation]. Sotsial'no-gumanitarnye znaniia, no. 3, pp. 161-174. (In Russ.).

Gegel, L. A. and Kazakova, E. O. (2018) Spetsialist po rabote s molodezh'iu: problemy podgotovki i vostrebovannosti [Youth specialist: Problems of training and demand]. Vysshee obrazovanie v Rossii, vol. 27, no. 2, pp. 88-94. (In Russ.).

Gegel, L. A., Kazakova, E. O. and Kosykh, O. I. (2016) Gosudarstvennaia molodezhnaia politika: rossiiskii i zarubezhnyi opyt preodoleniia ekstremizma [State youth policy: Russian and foreign experience in overcoming extremism]. Alma mater (Vestnik vysshei shkoly), no. 5, pp. 59-64. (In Russ.). DOI: 10.20339/ AM.05-16.059

Gurevich, P. S. (2008) [Rets. na kn.: Lukov V. A., Lukov Vl. A. Tezaurusy: sub"ektnaia organizatsiia gumanitarnogo znaniia. M., 2008. 784 s.] [A review on: Lukov, V. A. and Lukov, Vl. A. Thesauri: The subjective organization of humanities knowledge. Moscow, 2008. 784 p.]. Edip, no. 3 (6), pp. 165-166. (In Russ.).

Zavialova, N. A. (2018) Kul'turno-kommunikativnye formuly kak otrazhenie tsivilizatsionnykh kartin mira [Cultural and communicative formulas as a reflection of civilizational worldviews] : Abstract of the diss. ... Doctor of Culturology. Moscow. 40 p. (In Russ.).

Zakharov, N. V. (2008) Shekspirizm russkoi klassicheskoi literatury: tezaurusnyi analiz [Shakespearianism of Russian classical literature: The thesaurus analysis] : A monograph / ed. by Vl. A. Lukov. Moscow : Moscow University for the Humanities Publ. 320 p. (In Russ.).

Zubok, Yu. A. (2003) Problemy riska $v$ sotsiologii molodezhi [The issues of risk in sociology of youth]. Moscow : Moscow Academy for the Humanities and Social Sciences Publ. 268 p. (In Russ.).

Zubok, Yu. A. (2007) Fenomen riska v sotsiologii: opyt issledovaniia molodezhi [The phenomenon of risk in sociology: A study of the youth]. Moscow : Mysl’ Publ. 288 p. (In Russ.).

Ishchenko, Yu. A. (2009) Razmyshleniia nad knigoi [Lukov V. A., Lukov Vl. A. Tezaurusy: sub"ektnaia organizatsiia gumanitarnogo znaniia. M. : Izd-vo Nats. in-ta biznesa, 2008. 784 s.] [Reflections on book [Lukov, V. A. and Lukov, Vl. A. Thesauri: The subjective organization of humanities knowledge. Moscow : The National Institute of Business Publ., 2008. 784 p.]]. Znanie. Ponimanie. Umenie, no. 3, pp. 262-268. (In Russ.).

Kanarsh, G. Yu. (2020) Spravedlivost', demokratiia, kapitalizm: puti modernizatsii Rossii v XXI veke [Justice, democracy, capitalism: Ways to Russia's modernization in the 21st century] / Institute of Philosophy, RAS. Moscow : Lenand Publ. 304 p. (In Russ.). 
Kovaleva, A. I. et al. (2018a) Sotsiologiia molodezhi: nauchnaia shkola Moskovskogo gumanitarnogo universiteta [Sociology of youth: The school of thought at Moscow University for the Humanities] : in 2 pts. / A. I. Kovaleva, V. A. Lukov, V. A. Gnevasheva and S. V. Lukov. Moscow : Moscow University for the Humanities Publ. Pt. 2. 508 p. (In Russ.).

Kovaleva, A. I. et al. (2018b) Uchebno-vospitatel'nyi protsess v otsenkakh studentov (monitoring v Moskovskom gumanitarnom universitete: etap 2018 g.) [Educational process in students' assessments (Monitoring at Moscow University for the Humanities: The 2018 stage)] / A. I. Kovaleva, V. A. Lukov, V. A. Gnevasheva and S. V. Lukov. Gorizonty gumanitarnogo znaniia, no. 3, pp. 21-45. URL: http://journals.mosgu.ru/ggz/article/view/796 (accessed 19.01.2020). (In Russ.). DOI: 10.17805/ggz.2018.3.2

Kovaleva, A. I. and Levicheva, V. F. (2014) [Rets. na kn.:] Lukov Val. A. Teorii molodezhi: mezhdistsiplinarnyi analiz. M. : Izd-vo «Kanon+», 2012 [A review on: Lukov Val. A. Theories of the youth: An interdisciplinary analysis. Moscow : Kanon+ Publ., 2012]. Sotsiologicheskie issledovaniia, no. 4 (360), pp. 153155. (In Russ.).

Kovaleva, A. I. and Lukov, V. A. (1999) Sotsiologiia molodezhi: Teoreticheskie voprosy [The sociology of youth: Theoretical issues]. Moscow : Sotsium Publ. 351 p. (In Russ.).

Kostina, A. V. (2008) Tezaurusnyi podkhod kak novaia paradigma gumanitarnogo znaniia [The thesaurus approach as a new paradigm of humanities knowledge]. Observatoriia kul'tury, no. 5, pp. 102-109. (In Russ.).

Kuznetsova, T. F. (2014) O kontseptualizatsii molodezhi. Val. A. Lukov. Teorii molodezhi: mezhdistsiplinarnyi analiz. M. : «Kanon+» ROOI «Reabilitatsiia», 2012. 528 s. [On the conceptualization of the youth. Val. A. Lukov. Theories of the youth: An interdisciplinary analysis. Moscow : Kanon+ Publ., RPOD “Reabilitatsiia”, 2012]. Filosofskie nauki, no. 12, pp. 134-137. (In Russ.).

Kuznetsova, T. F. (2020) Tsifrovoe obshchestvo, tsifrovaia kul'tura i gumanitarizatsiia vysshego obrazovaniia: tezaurusnyi podkhod [Digital society, digital culture and humanitarization of the higher education: The thesaurus approach] : A research monograph. Moscow : Moscow University for the Humanities Publ. 192 p. (In Russ.).

Lamazhaa, Ch. K. (2012) Tezaurusnyi podkhod dlia tuvinovedeniia [The thesaurus approach for Tuvan studies]. Znanie. Ponimanie. Umenie, no. 2, pp. 3845. (In Russ.).

Lukov, V. A. (1987) Molodezhnoe dvizhenie v sotsialisticheskom obshchestve: Voprosy teorii i praktiki [Youth movement in a socialist society: Issues of theory and practice]. Moscow : Molodaia gvardiia Publ. 222 p. (In Russ.). 
Lukov, V. A. (2002) Tezaurusnaia kontseptsiia sotsializatsii [The thesaurus conception of socialization]. In: Diskurs: sotsiologicheskaia studiia [Discourse: Sociological studio]. Issue 2: Sotsial'naia struktura, sotsial'nye instituty i protsessy [Social structure, social institutes and processes] / ed. by V. A. Lukov. Moscow : Sotsium Publ. 239 p. Pp. 8-19. (In Russ.).

Lukov, V. A. (2012) Teorii molodezhi: mezhdistsiplinarnyi analiz [Theories of the youth: An interdisciplinary analysis]. Moscow : Kanon+ Publ., RPOD "Reabilitatsiia”. 528 p. (In Russ.).

Lukov, V. A. (2013) Biosotsiologiia molodezhi: teoretiko-metodologicheskie osnovaniia [Biosociology of youth: Theoretical and methodological foundations] : A monograph. Moscow : Moscow University for the Humanities Publ. 430 p. [online] Available at: http://mosgu.ru/nauchnaya/publications/2013/monograph/Lukov _Biosociology-of-Youth.pdf [archived in WaybackMachine] (accessed 19.01. 2020).

Lukov, V. A. (2018) Rossiiskaia molodezh' o biotekhnologicheskikh proektakh «uluchsheniia» cheloveka [Russian young people on biotechnological projects for human “enhancement”]. Sotsiologicheskie issledovaniia, no. 4 (408), pp. 73-81. (In Russ.). DOI: 10.7868/S0132162518040086

Lukov, V. A. (2019a) Sotsiokul'turnye osnovaniia sub"ektnosti rossiiskoi molodezhi (tezaurusnaia kontseptsiia molodezhi) [Sociocultural foundations of the Russian youth's subjectivity (Thesaurus conception of the youth)] : Abstract of the diss. ... Doctor of Sociology. Moscow. 42 p. (In Russ.).

Lukov, V. A. (2019b) Sotsiokul'turnye osnovaniia sub"ektnosti rossiiskoi molodezhi (tezaurusnaia kontseptsiia molodezhi) [Sociocultural foundations of the Russian youth's subjectivity (Thesaurus conception of the youth)] : Diss. ... Doctor of Sociology. Moscow. 438 p. [online] Available at: https://mosgu.ru/aspirantura/ dissovet/razmesenie_disser/july-2019/Диссертация\%20Вал.А.\%20Лукова.pdf [archived in WaybackMachine] (accessed 17.01.2020). (In Russ.).

Lukov, V. A. (2020) Sotsializatsiia molodezhi kak sistemoobrazuiushchee poniatie nauki ob obshchestve: tezaurusnyi podkhod [Socialization of youth as a system-forming concept of science about society: Thesaurus approach]. Uchenyi sovet, no. 4 (184), pp. 16-25. (In Russ.).

Lukov, V. A. and Lukov, Vl. A. (2008) Tezaurusy: sub"ektnaia organizatsiia gumanitarnogo znaniia [Thesauri: The subjective organization of humanities knowledge]. Moscow : The National Institute of Business Publ. 784 p. (In Russ.).

Lukov, V. A. and Lukov, V1. A. (2013) Tezaurusy II: tezaurusnyi podkhod k ponimaniiu cheloveka i ego mira [Thesauri II: The thesaurus approach to the conceptualization of the person and his/her world]. Moscow : The National Institute of Business Publ. 640 p. (In Russ.). 
Molodezhnaia politika $v$ sisteme formirovaniia grazhdanskoi identichnosti sovremennoi molodezhi [Youth policy in the system of civil identity formation among contemporary youth] (2018) : A multi-authored monograph / ed. by A. V. Bugaev and T. K. Rostovskaia. Moscow : Russian State Social University Publ. 198 p. (In Russ.).

Omelchenko, E. L. (2004) Molodezh': otkrytyi voprosy [Youth: Open-ended question]. Ulyanovsk : Simbirskaia kniga Publ. 181 p. (In Russ.).

Omelchenko, E. L. (2019) Unikalen li rossiiskii sluchai transformatsii molodezhnykh kul'turnykh praktik? [Is the Russian case of the transformation of youth cultural practices unique?]. Monitoring obshchestvennogo mneniia: ekonomicheskie i sotsial'nye peremeny, no. 1 (149), pp. 3-27. (In Russ.). DOI: 10.14515/ monitoring.2019.1.01

Omelchenko, E. L. and Poliakov, S. I. (2017) Kontsept kul'turnoi stseny kak teoreticheskaia perspektiva i instrument analiza gorodskikh molodezhnykh soobshchestv [The concept of cultural scene as theoretical perspective and the tool of urban communities analysis]. Sotsiologicheskoe obozrenie, vol. 16, no. 2, pp. 111132. (In Russ.). DOI: 10.17323/1728-192X-2017-2-111-132

Tezaurusy mirovoi kul'tury i literatury [Thesauri of world culture and literature] (2015) : Proceedings of the All-Russian virtual research-to-practice conference with international participants (March 19-20, 2015) / ed. by N. E. Erofeeva. Orsk : Orsk Humanities and Technology Institute (Branch) of Orenburg State University Publ. 133 p. (In Russ.).

Chuprov, V. I. (1994) Teoreticheskie i prikladnye problemy sotsial'nogo razvitiia molodezhi [Theoretical and applied issues of youth's social development] : Abstract of the diss. ... Doctor of Sociology. Moscow. 59 p. (In Russ.).

Yadov, V. A. (1994) Sotsial'naia identifikatsiia v krizisnom obshchestve [Social identification in crisis-ridden society]. Sotsiologicheskii zhurnal, no. 1, pp. 35-52. (In Russ.).

Submission date: 20.02.2020.

Ковалева Антонина Ивановна - доктор социологических наук, профессор, заведующий кафедрой социологии Московского гуманитарного университета. Адрес: 111395, Россия, г. Москва, ул. Юности, 5, корп. 1. Тел.: +7 (499) 374-60-21. Эл. адрес: socio-mosgu@mail.ru

Kovaleva Antonina Ivanovna, Doctor of Sociology, Professor, Head, Department of Sociology, Moscow University for the Humanities. Postal address: Bldg. 1, 5 Yunosti St., 111395 Moscow, Russian Federation. Tel.: +7 (499) 37460-21. E-mail: socio-mosgu@mail.ru 
Для изитирования:

Ковалева А. И. Социокультурная субъектность как основа тезаурусной концепции молодежи [Электронный ресурс] // Горизонты гуманитарного знания. 2020. № 1. С. 36-53. URL: http://journals.mosgu.ru/ggz/article/view/11 $\underline{61}$ (дата обращения: дд.мм.гггг). DOI: 10.17805/ggz.2020.1.3 